\title{
Organoleptic analysis of different composition of fruit juices containing wheatgrass
}

\author{
${ }^{1 *}$ Hasani, A. ${ }^{2}$ Kongoli, R. and ${ }^{2}$ Beli, D. \\ ${ }^{1}$ Faculty of Agriculture and Veterinary, Department of Food Technology, University of Prishtina "Hasan \\ Prishtina", Kosovo \\ ${ }^{2}$ Faculty of Biotechnology and Food, Agricultural University of Tirana, Albania
}

\begin{abstract}
Article history:
Received: 2 February 2018 Received in revised form: 7 March 2018

Accepted: 11 March 2018 Available Online: 12 March 2018
\end{abstract}

\section{Keywords:}

Wheatgrass juice,

Sensory analyses,

Novel food,

Functional food

\section{DOI:}

https://doi.org/10.26656/fr.2017.2(3).035

\begin{abstract}
The scope of this study was to evaluate sensory attributes and consumer acceptance of different composition of fruit juices containing wheatgrass. A 5-point hedonic scale evaluation test for acceptance was conducted with 43 non-professional panelists. Data collected from the evaluation forms were processed using Descriptive analysis and ANOVA. The juices involved in this research were also assessed for $\mathrm{pH}$, total soluble solids (TSS), titratable acidity, and sugar/acid ratio due to their direct interference in sensory attributes of juices. Mean acceptance of sensory attributes of the 6 samples varies from 2.65 to 3.68 . The best obtained range of sensory attributes was sample 7 (wheatgrass/ sour cherry/apple juice) with the mean value of acceptance $3.68 \pm 0.39$. The less accepted with a mean value of acceptance $2.65 \pm 0.348$ was sample 9 (wheatgrass/apricot/wild apple juice). The most liked sample has a higher TSS value of $12^{\circ}$ Brix, as well as the second highest sugar/acid ratio of $38.7^{\circ} \mathrm{Brix} / \%$ acid. Whilst, the less accepted formulation was sample 9 which has the lowest $\mathrm{pH}$ value of 3.45 , higher acidity $6.03 \mathrm{~g} / 1 \mathrm{malic}$ acid, and lower value of sugar/acid ratio of $19.16^{\circ} \mathrm{Brix} / \%$ acid. The tests revealed an average of good sensory acceptance of the different composition of fruit juices containing the high extraction yield of wheatgrass, thus suggesting a good commercial potential for the products.
\end{abstract}

\section{Introduction}

Green juices containing wheatgrass are considered nowadays novel functional foods, super food or specific food, because of their high content of health promoting nutritions such as antioxidants, polyphenols, chlorophyll, amino acids, minerals, vitamins, active enzymes and other nutrients. Nowadays, there is increased consumer demand for high-antioxidant foods. Drinking highantioxidant beverages may help to protect against aging, Alzheimer's disease, and other chronic diseases (Nanasombat et al., 2015). Cereal grasses (young shoots of grain-bearing plants) including alfalfa, barley grass, wheatgrass are one such type of Green foods which are very beneficial for a healthy body (Ashish et al., 2012). The wheatgrass refers to the young grass of the common wheat plant, Triticum aestivum that is freshly juiced or dried into powder for animal and human consumption. Both provide chlorophyll, amino acids, minerals, vitamins, and enzymes. Wheatgrass is a humble weed that is a powerhouse of nutrients and vitamins for the human body. In the form of fresh juice, it has high concentrations of chlorophyll, active enzymes, vitamins and other nutrients (Mujoriya and Bodla, 2011). Wheatgrass is proven to have high antioxidant activity. Antioxidant activity of the wheatgrass juice was compared with the standard drug ascorbic acid. From the graph of percent inhibition and IC50, it shows that wheatgrass juice has significant antioxidant activity that is comparable to the standard drug ascorbic acid (Ashok, 2011). Wheatgrass juice is an integral part of the macrobiotic diet under the complementary and alternative medicine (CAM) approach of anticancer therapy, due to its high antioxidant content (Padalia et al., 2010). Changing in consumers' lifestyles and food consumption patterns provide a great opportunity for developing the functional food sector (Rezai et al., 2012). Such a functional food is considered also the Wheatgrass. Comprehensive data from a number of studies have revealed the multitude effects of wheatgrass in thalassemia, hemolytic anemia, cancer, asthma, allergy, inflammatory bowel disease, and detoxification. The structural homology of chlorophyll with hemoglobin indicates the role of chlorophyll as a blood builder in 
various clinical conditions involving hemoglobin deficiency - thus the name "green blood". To conclude, the wheatgrass seems to be a very promising herbal drug (Padalia et al., 2010). The $\mathrm{pH}$ (hydrogen molecules) value of both human blood and wheatgrass is about 7 (alkaline) and is therefore quickly absorbed in the blood and is highly beneficial (Mujoriya and Bodla, 2011). Functional drinks are a novelty in the region and in Kosovo as well. Since from the literature review, it is not found any previous similar work conducted in this field, we considered important to undertake this study as a preliminary study which will be developed furthermore in the future.

The aim of this study was to evaluate the sensory characteristics and the consumer acceptance of wheatgrass juice in 6 different $100 \%$ fruit juices formulation. The commercial juices involved in this research were: apple juice, wild apple (Malus sylvestris) juice, strawberry and apple (30:70) juice, sour cherry and apple (30:70) juice, peach and apple (30:70) juice, apricot and apple (30:70) juice. In addition, the objective of the study was also to understand the perceptions of functional food in Kosovo and, the marketability of these products in the future. Further analysis will be undertaken with the potential consumers of these products. We consider that this study will provide a useful insight into production and marketing strategies for a new functional food line - green juices containing wheatgrass.

\section{Materials and methods}

Green juice extracted from wheatgrass and commercial pasteurized 100\% apple, wild apple (Malus sylvestris), strawberry, sour cherry and apple juice, peach and apricot juice (produced by MOEA/Frutomania LLC in Kravarice, Gjilan Kosovo) were used in this research.

\subsection{Juice extraction}

Experimental land plots were planted with wheatgrass to be harvested on their 'jointing' stage; the second leaf grown after the half of the first leaf. Then, the grasses were cleaned and immediately juiced and stored in the refrigerator at $7^{\circ} \mathrm{C}$ until the next day when the sensory analyses took place. The juicing was conducted using a fruit, vegetable and wheatgrass juicer, Omega 8224 Nutrition Center Juicer, which was a masticating style juice extractor. It can juice at low speeds - 80 RPM that minimizes heat build-up and oxidation. The result is a healthy fresh juice with high enzyme content that health conscious individuals crave for. Nutrition centers are engineered with powerful components that can easily extract juice from wheatgrass and leafy vegetables.

\subsection{Formulation}

Six formulations were prepared using the freshly extracted wheatgrass juice and the commercial, pasteurized, $100 \%$ fruit juices, produced in MOEA L.L.C Kosovo. The commercial juices involved in this research were: apple juice, wild apple (Malus sylvestris) juice, strawberry and apple (30:70) juice, sour cherry and apple (30:70) juice, peach and apple (30:70) juice, apricot and apple (30:70) juice. The composition of the formulations involved in this research and their sample code is shown in Table 1.

\subsection{Physical, physico-chemical and chemical analysis}

The wheatgrass juice and its respective formulations with commercial, pasteurized, fruit juices were analyzed by using standardized methods for the $\mathrm{pH}$ (AOAC, 1982), TSS (AOAC, 1999) and titratable acidity (AOAC, 1999). To determine the sugar/acid ratio, the sugar concentration ( ${ }^{\circ}$ Brix) was divided by the $\%$ acid concentration.

\subsection{Sensory analysis}

A 5-point hedonic scale evaluation test for acceptance was conducted with 43 non-trained panelists. From the 43 non-trained panelists, there were 11 males and 32 females, aged 18-32. The reason for this young population involvement relied on the fact that all the panelist were students of the Department of Food Technology and were selected since they have undergone some basic training on sensory evaluation during their coursework, although they were not

Table 1. wheatgrass and fruit juice formulations used in the research

\begin{tabular}{cccccccc}
\hline \multirow{2}{*}{$\begin{array}{c}\text { Sample } \\
\text { code }\end{array}$} & Wheatgrass & Apple & $\begin{array}{c}\text { Wild } \\
\text { apple }\end{array}$ & $\begin{array}{c}\text { Strawberry and } \\
\text { apple (30:70) }\end{array}$ & $\begin{array}{c}\text { Sour cherry and } \\
\text { apple (30:70) }\end{array}$ & $\begin{array}{c}\text { Peach and } \\
\text { apple (30:70) }\end{array}$ & $\begin{array}{c}\text { Apricot and } \\
\text { apple (30:70) }\end{array}$ \\
\cline { 2 - 8 } & 30 & 70 & 0 & 0 & 0 & 0 & 0 \\
5 & 15 & 60 & 25 & 0 & 0 & 0 & 0 \\
6 & 15 & 0 & 25 & 60 & 0 & 0 & 0 \\
7 & 30 & 0 & 0 & 0 & 0 & 60 & 0 \\
8 & 15 & 0 & 25 & 0 & 0 & 0 & 60 \\
9 & 15 & 0 & 25 & 0 & 0 & 0 & 0 \\
\hline
\end{tabular}


professional degustators. The evaluation scale was $1=$ unacceptable - disliked extremely, 2 = bad - disliked moderately, 3 = average - neither liked nor disliked, $4=$ good - moderately liked, 5 = excellent - extremely liked. The panelists were asked to evaluate the following sensory attributes: appearance/color, aroma, the intensity of aroma, taste, consistency and overall perception. The order of sample presentation was completely randomized for each panelist (Wakeling and MacFie, 1995). The panelists were divided into two groups, first group of 22 panelists evaluated samples with codes $4-6$, and the second group of 21 panelists evaluated samples 6-9. Sample 6 was given to both groups for the control effect. Additional information concerning the sex and age were asked at the end of the test in order to characterize the population sample.

\subsection{Statistical analysis}

The obtained primary data was then analyzed mainly by using ANOVA and descriptive statistics. Descriptive statistics of the evaluation of organoleptic traits of wheatgrass formulations with fruit juices (mean acceptance, standard deviation, and coefficient of variation) were calculated by general statistic methods. $T$ -test pair comparison was conducted to determine if there is a statistical difference between the two groups of degustators in product attribute evaluation score for the control sample (sample 6 - strawberry and apple (30:70) juice). The analysis of variance $\mathrm{p}<0.05$ was used to observe if there are statistical different evaluation scores from degustation of six samples involved in this research for 5 attributes as described above.

\section{Results and discussion}

The results obtained from physical, physicochemical and chemical analyses for six formulations of fruit juices with wheatgrass (samples 4, 5, 6, 7, 8, and 9) are tabulated in Table 2 . The $\mathrm{pH}$ of freshly extracted wheatgrass was 6.93 for wheatgrass. The $\mathrm{pH}$ value of wheatgrass 24 hours after harvesting was 6.43 . The reason for this low $\mathrm{pH}$ value could be seen in the fact that the wheatgrass juice was extracted one day before the sensory test was carried out and kept in the refrigerator at $7^{\circ} \mathrm{C}$. TSS for wheatgrass was $3.5^{\circ}$ Brix, while its titratable acidity was $2.34 \mathrm{~g} / 1$ malic acid, acidity in percentage was $0.23 \%$ and its sugar/acid ratio was $15.21^{\circ} \mathrm{Brix} / \%$ acid.

\subsection{Sensory analyses}

The average ratings, standard deviations, and coefficients of variation were initially calculated for all the panelists for each analyzed feature, including appearance/color, aroma, intensity of aroma, taste, consistency, and overall perception. These values along with the mean acceptance, mean $\mathrm{SD}$, and mean $\mathrm{CV}$ parameters are shown in following Table 3.

Mean acceptance of sensory attributes of the 6 samples varies from 2.65 to 3.68 . The best ranged or best accepted by consumers was sample 7 - wheatgrass/sour cherry/apple juice- with the mean value of acceptance $3.68 \pm 0.390$ and CV 0.106. The less accepted or ranged with a mean value of acceptance $2.65 \pm 0.348$, and $\mathrm{CV}$ 0.131 was sample code 9 - wheatgrass/apricot/wild apple juice. If we look carefully at Table 2 on physical, physico-chemical and chemical analysis, it is evident that unlike other samples, the most liked sample has the higher TSS value of $12^{\circ} \mathrm{Brix}$, as well as second highest sugar/acid ratio of $38.7^{\circ} \mathrm{Brix} / \%$ acid. Whilst, the least liked or accepted formulation, sample code 9 , has the lowest $\mathrm{pH}$ value of 3.45 , the higher acidity $6.03 \mathrm{~g} / 1$ malic acid, and the lower value of sugar/acid ratio of $19.16^{\circ} \mathrm{Brix} / \%$ acid. Thus, it is concluded than less acidic formulations and higher content of sugar is preferred. This conclusion matches also many of the suggestions of the panelists who declared that they would prefer a sweeter taste. Among the comments and the suggestions, it was found also the need for improving the taste by sweetening, enhancement of aroma of fruit juices and melioration of consistency by elimination precipitation problem. The organoleptic evaluation for appearance/ color, aroma, aroma intensity, taste, consistency, and general impression for each sample is given by following graphic illustrated in Figure 1.

The wheatgrass juice extracted using Omega 8224 Nutrition Center Juicer yielded $0.71 / \mathrm{kg}$ grass. The tests revealed an average to good sensory acceptance and a high extraction yield, thus suggesting a good commercial potential for the products.

As mentioned above, for control effect purposes, sample 6 was presented to both groups of degustators. T -test pair comparison was conducted to determine if there is a statistical difference between the two groups of degustators in product attribute evaluation score for the sample 6 (strawberry and apple (30:70) juice). The results show that there are statistical differences in flavor intensity and taste between the two groups of degustators. Results of this test are presented in Table 4.

The analysis of variance $(\mathrm{p}<0.05)$ showed statistical difference was observed on attributes such as flavor (Fvalue $=3.872 ; \mathrm{p}$-value 0.028$)$ taste $(\mathrm{F}$-value $=6.755 ; \mathrm{p}$ value 0.002$)$ and general perceptions ( $\mathrm{F}$-value $=4.496, \mathrm{p}$ -value 0.026) from the degustation on sample 4. As for sample 5, there are different evaluations on attributes such as the color attribute (F-value $=7.096 ; \mathrm{p}$-value $0.005)$ and the general perception $(\mathrm{F}-\mathrm{value}=3.442$, $\mathrm{p}$ - 
Table 2. $\mathrm{pH}$, Total Soluble Solids (TSS), total titrable acidity (TTA), sugar/acid ratio

\begin{tabular}{clccccc}
\hline $\begin{array}{c}\text { Sample } \\
\text { code }\end{array}$ & \multicolumn{1}{c}{ Sample formulation } & $\mathrm{pH}$ & $\begin{array}{c}\text { TSS } \\
\left({ }^{\circ} \text { Brix }\right)\end{array}$ & $\begin{array}{c}\text { Titratable Acid } \\
(\mathrm{g} / \mathrm{l} \text { malic acid })\end{array}$ & $\begin{array}{c}\text { Acidity } \\
(\%)\end{array}$ & $\begin{array}{c}\text { Sugar/acid ratio } \\
\left({ }^{\circ} \mathrm{Brix} / \% \mathrm{ocid}\right)\end{array}$ \\
\hline 4 & wheatgrass/apple juice & 3.77 & 9 & 2.01 & 0.20 & 45 \\
5 & wheatgrass/apple/wild apple juice & 3.56 & 8 & 2.67 & 0.27 & 29.6 \\
6 & wheatgrass /strawberry-apple juice & 3.73 & 9.5 & 4.02 & 0.40 & 23.7 \\
7 & wheatgrass/sour cherry-apple juice & 3.77 & 12 & 3.08 & 0.31 & 38.7 \\
8 & wheatgrass/peach-apple juice/wild apple juice & 3.69 & 11.2 & 3.81 & 0.38 & 36.1 \\
9 & wheatgrass/ apricot- apple juice/wild apple juice & 3.45 & 11.5 & 6.03 & 0.60 & 19.16 \\
\hline
\end{tabular}

Table 3. Average rating of analyzed features for all samples. Values of mean acceptance \pm standard deviation (SD) and coefficient of variation (CV) for all samples involved is this test.

\begin{tabular}{ccccccccc}
\hline $\begin{array}{c}\text { Sample } \\
\text { code }\end{array}$ & $\begin{array}{c}\text { Appearance } \\
\text { / Color }\end{array}$ & Aroma & $\begin{array}{c}\text { Aroma } \\
\text { intensity }\end{array}$ & Taste & Consistency & $\begin{array}{c}\text { General } \\
\text { Impression }\end{array}$ & $\begin{array}{c}\text { Mean Acceptance } \pm \\
\text { SD }\end{array}$ & $\begin{array}{c}\text { Mean } \\
\text { CV }\end{array}$ \\
\hline 4 & 3.45 & 2.64 & 3.50 & 3.41 & 2.91 & 3.55 & $3.24 \pm 0.343$ & 0.106 \\
5 & 3.27 & 2.64 & 3.31 & 2.77 & 2.77 & 3.14 & $2.98 \pm 0.265$ & 0.089 \\
6 & 3.24 & 3.33 & 4.42 & 3.01 & 3.31 & 3.43 & $3.45 \pm 0.451$ & 0.130 \\
7 & 4.36 & 3.10 & 3.65 & 3.43 & 3.62 & 3.90 & $3.68 \pm 0.39$ & 0.106 \\
8 & 2.90 & 2.62 & 3.45 & 2.52 & 2.95 & 2.86 & $2.88 \pm 0.297$ & 0.103 \\
9 & 2.98 & 2.19 & 2.54 & 2.33 & 3.19 & 2.67 & $2.65 \pm 0.348$ & 0.131 \\
\hline
\end{tabular}

Table 4. T-test pair comparisons for evaluation of control sample (6) among two groups of degustators

\begin{tabular}{llcccc}
\hline \multicolumn{2}{c}{ Pair comparisons of attributes } & $\mathrm{Mean}$ & $\mathrm{t}$ & $\mathrm{df}$ & Sig. (2-tailed) \\
\hline Pair 1 & Appearance/ Color_6 & .429 & 1.574 & 20 & .131 \\
Pair 2 & Aroma_6 & -.095 & -.418 & 20 & .680 \\
Pair 3 & Aroma intensity _6 & .714 & 2.251 & 20 & .036 \\
Pair 4 & Taste_6 & .857 & 3.286 & 20 & .004 \\
Pair 5 & Consistency & -.190 & -.623 & 20 & .540 \\
Pair 6 & General Impression & .143 & .719 & 20 & .480 \\
\hline
\end{tabular}

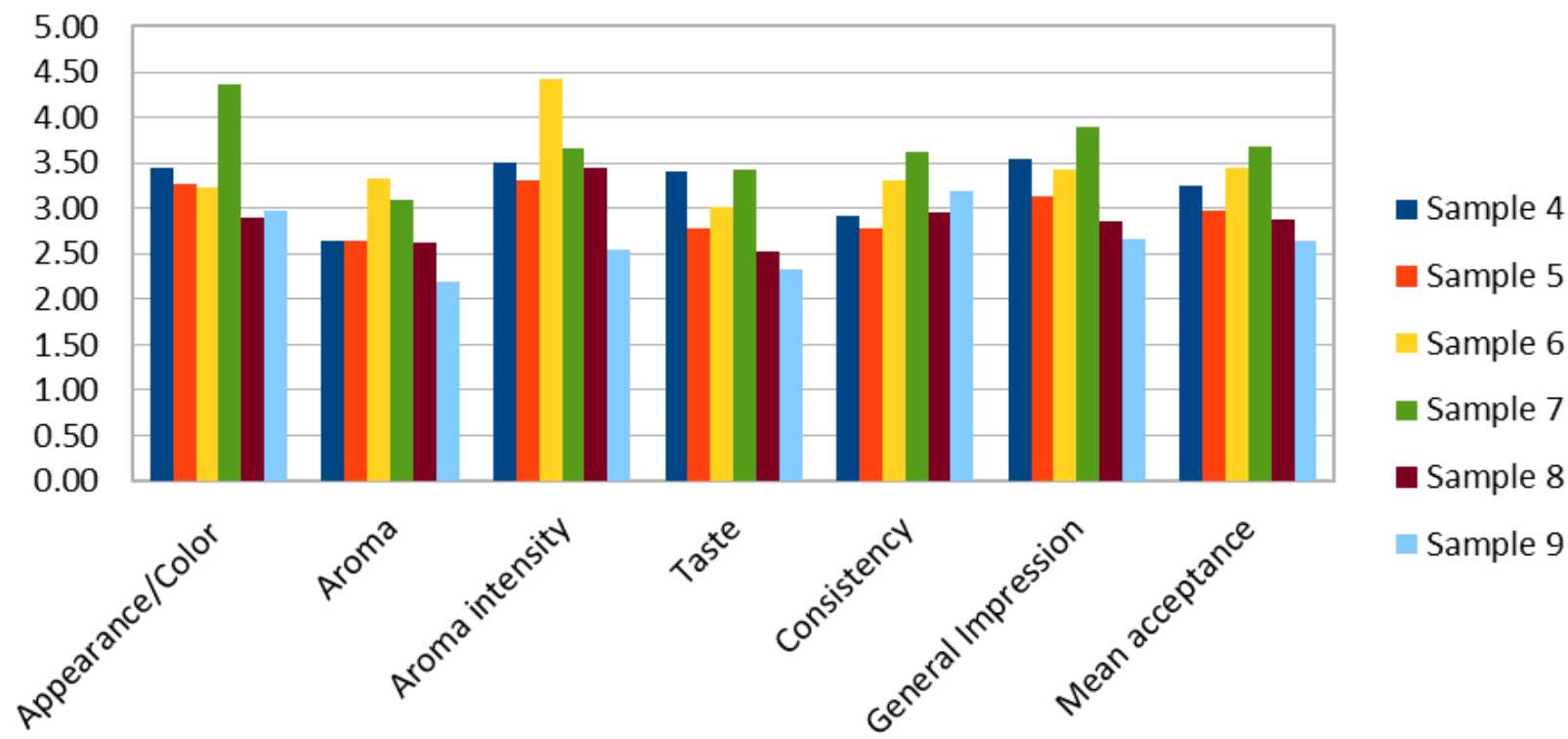

Figure 1. Data analysis on rating of all features for all samples involved in this research. 
value 0.054$)$. It seems to be evaluated differently by the consumers. As for sample 6, no statistical difference were observed among the attribute evaluation. For sample 7 , there were different evaluations among the degustators for the color $(\mathrm{F}$-value $=6.232 ; \mathrm{p}$-value $=$ 0.005 ) while other attributes showed no statistical difference. For sample 8 , we had a different perception among degustators for the attributes of color (F-value $=$ 3.151 ; p-value 0.043$)$ and for aroma $(F-$ value $=3.058$; $p$ value 0.057 ). For sample 9 , statistically differences were associated for the attribute of aroma (F-value $=3.077$; $\mathrm{p}$ value 0.043 ).

\subsection{Correlation analysis}

A high correlation value for general Impression (0.97) was observed for the taste and the lowest for consistency (0.50). Whilst for the mean acceptance, the highest correlation value was obtained for the two traits taste and aroma (0.88) and the lowest correlation obtained was consistency $(0.62)$.

\section{References}

AOAC (1982). PH of acidified foods. (981.12-1982). Retrieved August 17, 2016, from http:// www.aoacofficialmethod.org/index.php? main_page=product_info\&products_id $=1159$

AOAC. (1999). Acidity (Titratable) of Fruit Products (942.15). Retrieved August 17, 2016, from http:// www.eoma.aoac.org/methods/info.asp?ID=15499

AOAC. (1999). Measurement of Total Fructan in Foods (45.4.06B). Retrieved from: http://down.40777.cn/ stardard/8/45.4.06B\%20AOAC\%20Official\% 20Method $\% 20999.03 \% 20$ Measurement $\% 20$ of $\%$ 20Total\%20Fructan.pdf

Ashish, S., Shilpa, K., Singh, R.R. and Sanjay, K. (2012). Wheatgrass: an alternative household nutritional food security. International Research Journal of Pharmacy, 3(7), 246-250

Ashok, S.A. (2011). Phytochemical and pharmacological screening of wheatgrass juice (Triticum aestivum L.). International Journal of Pharmaceutical Sciences Review and Research, 9(1), 159-164.

Mujoriya, R. and Bodla, R.B. (2011). A study on wheatgrass and its Nutritional value. Food Science and Quality Management, 2, 1-9.

Nanasombat, S., Thonglong, J. and Jitlakha, J. (2015). Formulation and characterization of novel functional beverages with antioxidant and antiacetylcholinesterase activities. Functional Foods in Health and Disease, 5(1), 1-16

Padalia, S., Drabu, S., Raheja, I., Gupta, A. and Dhamija, M. (2010). Multitude potential of wheatgrass juice
(Green Blood): An overview. Chronicles of Young Scientists, 1(2), 23-28

Rezai, G., Teng, P.K., Mohamed, Z. and Shamsudin, M.N. (2012). Functional food knowledge and perceptions among young consumers in Malaysia. World Academy of Science, Engineering and Technology, 63, 307-312.

Wakeling, I.N. and MacFie, H.J.H. (1995). Designing consumer trials balanced for first and higher orders of carry-over effect when only a subset of k samples from t may be tested. Food Quality and Preference, 6(4), 299-308. https://doi.org/10.1016/0950-3293 (95)00032-1 